\title{
Penetrating Structures of Anaerobic Rumen Fungi in Cattle and Swamp Buffalo
}

\author{
By Y.W. HO, ${ }^{*}$ N. ABDULLAH ${ }^{2}$ AND S. JALALUDIN ${ }^{3}$ \\ ${ }^{1}$ Department of Biology, ${ }^{2}$ Department of Biochemistry and Microbiology, and ${ }^{3}$ Department of \\ Animal Science, Faculty of Science and Environmental Studies, Universiti Pertanian Malaysia, \\ 43400 Serdang, Selangor, Malaysia
}

(Received 2 June 1987; revised 3 August 1987)

\begin{abstract}
Rhizoids of anaerobic fungi colonizing fragments of guinea grass and rice straw in the rumen of cattle and swamp buffalo produced appressorium-like structures for penetration of the plant cell walls. These structures were generally lobed vesicles with fine penetration pegs, which penetrated through the cell wall and then expanded and continued their growth in adjacent cells, forming normal rhizoids which would in turn produce more 'appressoria' for penetration of the next cell. Their size and form varied with the size of the cell in which they developed. Small, flat 'appressoria' were produced in cells with small lumina while bigger and longer 'appressoria' developed in larger cells. 'Appressoria' were clearly observed in rhizoids of fungi colonizing the plant fragments about $1 \mathrm{~h}$ after incubation in the rumen and were produced in rumen fungi with spherical, oval or ovoid sporangia.
\end{abstract}

\section{INTRODUCTION}

About a decade ago, anaerobic phycomycete fungi were found to form part of the microbial population in the rumen of a wide range of herbivores consuming a high fibre diet (Orpin, 1975, 1976, $1977 a, 1981 a$; Bauchop, $1979 a, b$ ). The population density of these rumen anaerobic fungi was high when the host animal was fed with stalky, fibrous diets but they occurred in low numbers or were absent when the animal received soft, leafy diets (Bauchop, 1979b). The fungi preferentially colonized fibrous plant materials and were often associated with the vascular tissues of stems and leaves. The attachment and colonization of the fungi on various types of plant materials has been extensively studied (Orpin, $1977 a, b, 1981$; Bauchop, $1979 a, b, 1981$; Akin et al., 1983). Rhizoids of the fungi were reported to grow deep into the plant tissues, penetrating and degrading cell walls, and thereby weakening and disrupting the plant tissues. No mention was made of any special structures developed by the rhizoids for penetration of the cell walls.

In the present study, the rhizoids of many anaerobic fungi in the rumen of cattle and swamp buffalo were observed to produce highly specialized lobed structures for penetrating the plant cell walls.

\section{METHODS}

Animals. Two Kedah Kelantan cattle (Bos indicus) and two swamp buffaloes (Bubalus bubalis), all male and about 1.5 years old, were kept in single pens with free access to drinking water and mineral blocks. Each animal was fitted with a rumen cannula and fed once daily with guinea grass (Panicum maximum) ad libitum.

Plant materials. Fresh guinea grass, cut to about $4 \mathrm{~mm}$ length, and dried rice straw (Oryza sativa), ground through a $4 \mathrm{~mm}$ sieve, were placed separately in nylon bags (mesh size $50 \mu \mathrm{m}$ ) and suspended in the rumen. The bags were removed at timed intervals, rinsed in water and the plant fragments were immediately fixed in the appropriate solutions.

Preparation for scanning electron microscopy. The plant fragments were fixed in $4 \%(\mathrm{v} / \mathrm{v})$ glutaraldehyde in $0.2 \mathrm{M}-$ sodium cacodylate buffer, $\mathrm{pH} 7 \cdot 2$, at $4^{\circ} \mathrm{C}$ for $1-2 \mathrm{~d}$. These fragments were then washed three times in $0 \cdot 1 \mathrm{M}$ - 


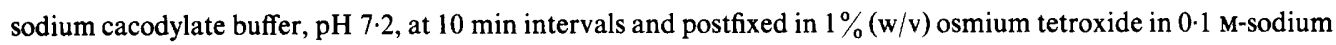
cacodylate buffer, $\mathrm{pH} 7.2$, for $2 \mathrm{~h}$ before similar washings were repeated. The samples were dehydrated in ascending concentrations of acetone: $30 \%, 50 \%, 75 \%(10 \mathrm{~min}$ each $) ; 95 \%(15 \mathrm{~min})$; and three times with $100 \%$ ( $15 \mathrm{~min}$ each). They were then dried in a critical point drier for $2 \mathrm{~h}$, mounted on stubs and coated with gold for $5 \mathrm{~min}$ in a sputter coater before being examined with a JSM 35C scanning electron microscope (JEOL).

Preparation for light microscopy. The fragments were fixed in formalin/acetic acid $/ 50 \%(\mathrm{v} / \mathrm{v})$ ethanol $(1: 1: 18$, by vol., FAA) overnight, then placed in $5 \%(\mathrm{w} / \mathrm{v})$ sodium hydroxide at $37^{\circ} \mathrm{C}$ (with several changes) until they had lost most of their chlorophyll. The fragments were then washed twice in distilled water and placed in chloral hydrate solution ( $50 \mathrm{~g}$ in $30 \mathrm{ml}$ water) until the chlorophyll was completely cleared. These fragments were rinsed in water and stained with cotton blue-lactophenol (BDH).

Plant fragments were also sectioned for examination by light microscopy. The fragments were fixed in FAA, dehydrated in 70\%,80\% and 90\% ethanol (30 min each) and $100 \%$ ethanol (30 min, twice), and infiltrated with and embedded in Paraplast (purified paraffin and plastic polymers with dimethyl sulphoxide; Paraplast + , Lancer USA Sherwood Medical). Sections of 10-12 $\mu \mathrm{m}$ thickness were cut with a 820 Spencer AO rotary microtome. The sections were cleared and stained with safranin-aniline blue and picric acid (Peacock, 1973) or with safranin and fast green (Johansen, 1940).

\section{RESULTS AND DISCUSSION}

Attachment of zoospores of the rumen fungi to guinea grass and rice straw fragments occurred very rapidly - about 15-20 min after incubation in the rumen of cattle and buffalo. Sites for attachment were mainly the damaged surfaces, cut ends and stomata. Similar sites for zoospore attachment were reported by Bauchop $(1979 b, 1981)$ and Orpin $(1977 a, b, 1981 b)$. The attached and encysted zoospore then germinated with a single germ tube, which entered the cell lumen through the damaged cell wall or into the air space under the stoma through the stomatal opening. The germ tube very quickly branched to form numerous rhizoids.

When the rhizoids came in contact with the undamaged rigid cell wall, special lobed structures which resembled appressoria were produced (Fig. 1) by the rhizoids. Sometimes unbranched germ tubes in the cell lumen also developed these appressorium-like structures on contact with the cell wall. The 'appressoria' first emerged from the rhizoids (or germ tubes) as small knob-like protrusions (Fig. 1), which soon enlarged to form lobed vesicles (Fig. 1). Rhizoids with 'appressoria' were observed in the thin-walled mesophyll and parenchyma cells of guinea grass and rice straw fragments about $1 \mathrm{~h}$ after rumen incubation in cattle and swamp buffalo. At $6 \mathrm{~h}$, their numbers had increased and could be easily distinguished at low magnification in the light microscope (Fig. 2) and by $24 \mathrm{~h}$, the 'appressoria' were found abundantly in the thick-walled sclerenchyma and vascular tissues of the plant fragments.

The 'appressoria' were generally multi-lobed vesicles (5-10 lobes), 1.4-16.8 $\mu \mathrm{m}$ (diameter) $\times$ 1.0-12.6 $\mu \mathrm{m}$ (thickness); sessile or stalked; symmetrical with prominent uniform lobes, or asymmetrical with lobes of unequal sizes or with unpronounced lobes; flat, like a disc or longish resembling a flower bud (Fig. 3). A single fungus could produce the various types of 'appressoria' in its rhizoids. The size and form of the 'appressoria' varied with the size of the cell in which they developed. Flat and sessile 'appressoria' developed in cells with narrow cell lumina such as sclerenchyma cells and some xylem elements. Bigger 'appressoria', both stalked and sessile, were frequently formed in the larger mesophyll or parenchyma cells.

On contact with the cell wall, the 'appressorium' produced a fine penetration peg about $0.5-$ $0.8 \mu \mathrm{m}$ in diameter (Fig. 3), which penetrated the cell wall. Penetration was usually accomplished by means of a narrow bore or canal made at the point of contact between the penetration peg and the cell wall (Fig. 4). Once the penetration peg had penetrated through the cell wall, it expanded and continued to grow and elongate in that cell forming normal rhizoids which would in turn develop more 'appressoria' to penetrate the adjacent cells (Figs 5 and 6). After penetration of the cell wall, the 'appressoria' very often lost their prominent lobes, becoming irregular-shaped vesicles, and the penetration pegs become isthmuses connecting the vesicular 'appressoria' with the rhizoids (Fig. 6).

Rumen fungi which produced 'appressoria' in guinea grass and rice straw fragments were mainly those with spherical, oval or ovoid sporangia. Whether fungi with cylindrical, filiform or fusiform sporangia also produce 'appressoria' needs to be established by further studies. 


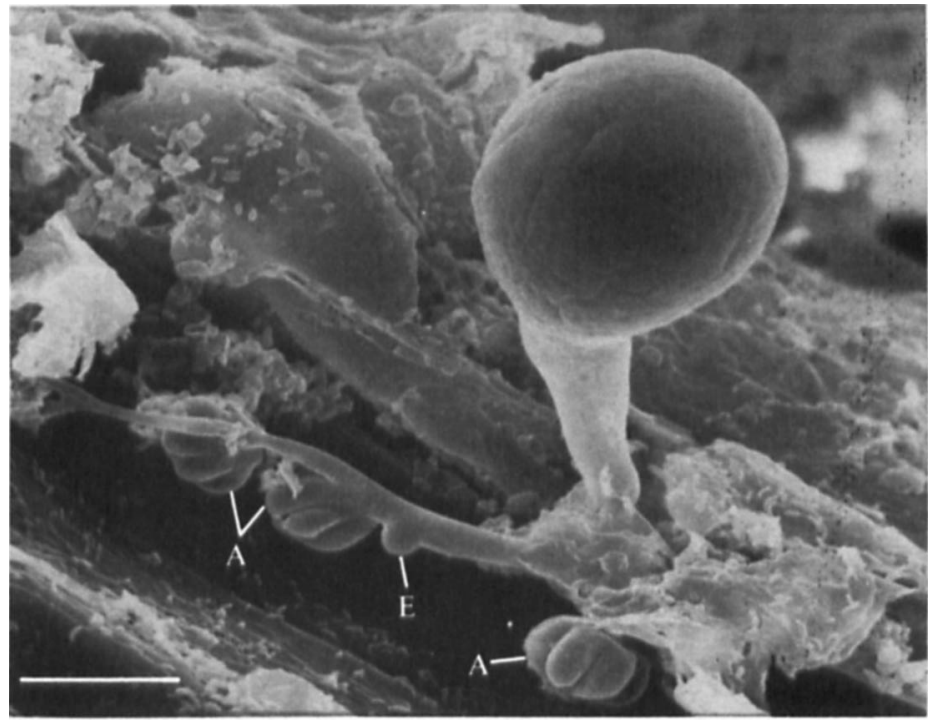

Fig. 1. Rumen fungus showing rhizoid with emerging (E) and developed (A) 'appressoria' in cell lumen of guinea grass from the rumen of cattle. Bar, $10 \mu \mathrm{m}$.

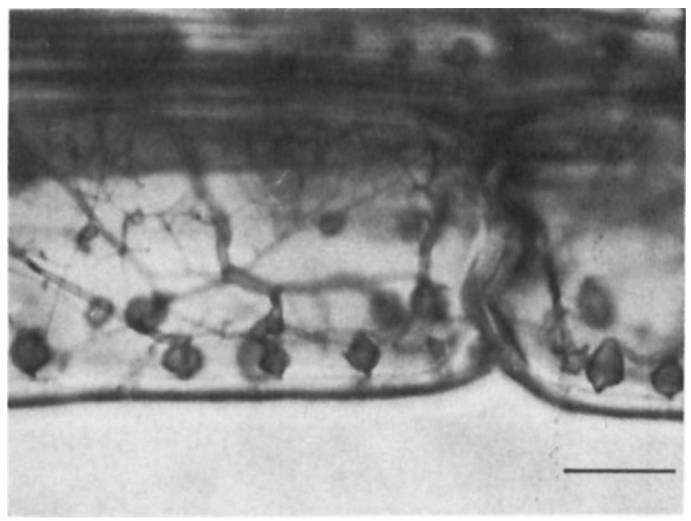

Fig. 2. Longitudinal section of parenchyma cells of guinea grass from the rumen of swamp buffalo showing rhizoids with numerous 'appressoria' directed towards the cell walls. Bar, $20 \mu \mathrm{m}$.

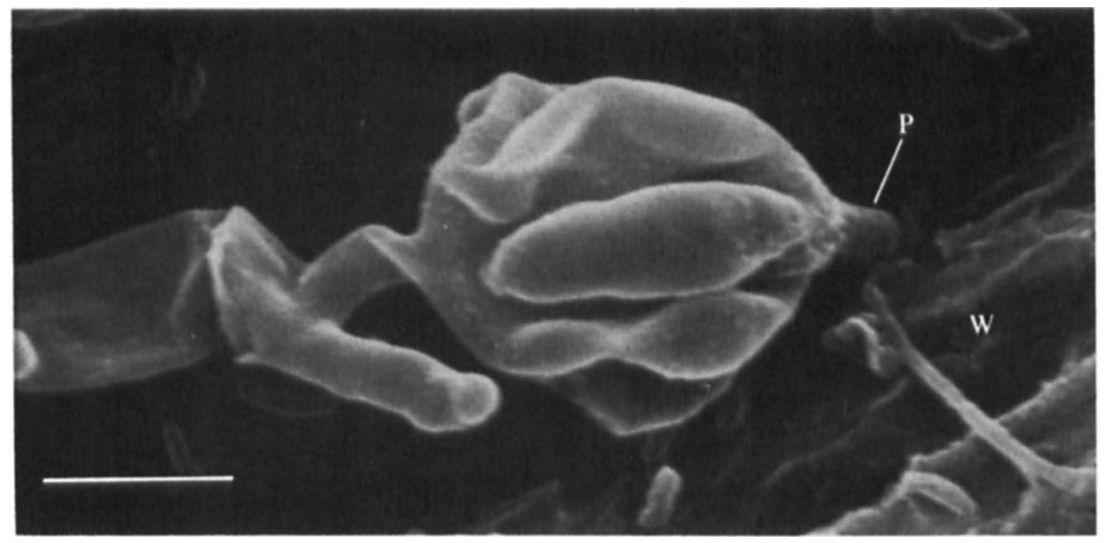

Fig. 3. 'Appressorium' with penetration peg $(\mathrm{P})$ on the cell wall $(\mathrm{W})$ of rice straw from the rumen of cattle. Bar, $2 \mu \mathrm{m}$. 


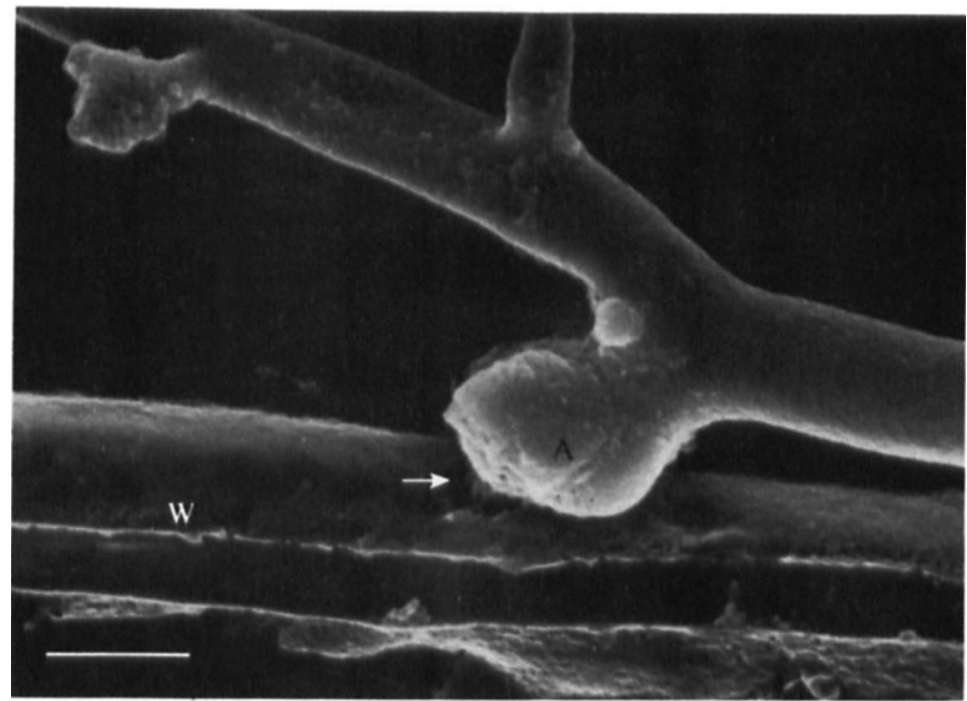

Fig. 4. 'Appressorium' (A) with penetration peg penetrating the cell wall (W) of rice straw from the rumen of cattle. Note the narrow bore or canal (arrow) made at the point of contact between the penetration peg and the cell wall. Bar, $2 \mu \mathrm{m}$.

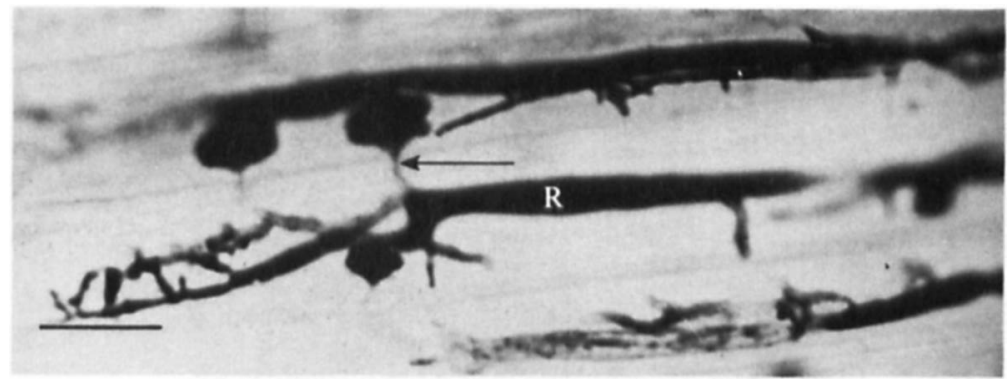

Fig. 5. Longitudinal section of cells of guinea grass from the rumen of cattle showing 'appressorium' with penetration peg (arrow) which had penetrated through the cell wall and had expanded and elongated in the adjacent cell forming a normal rhizoid $(R)$ which in turn produced more 'appressoria' to penetrate the next cell. Bar, $10 \mu \mathrm{m}$.

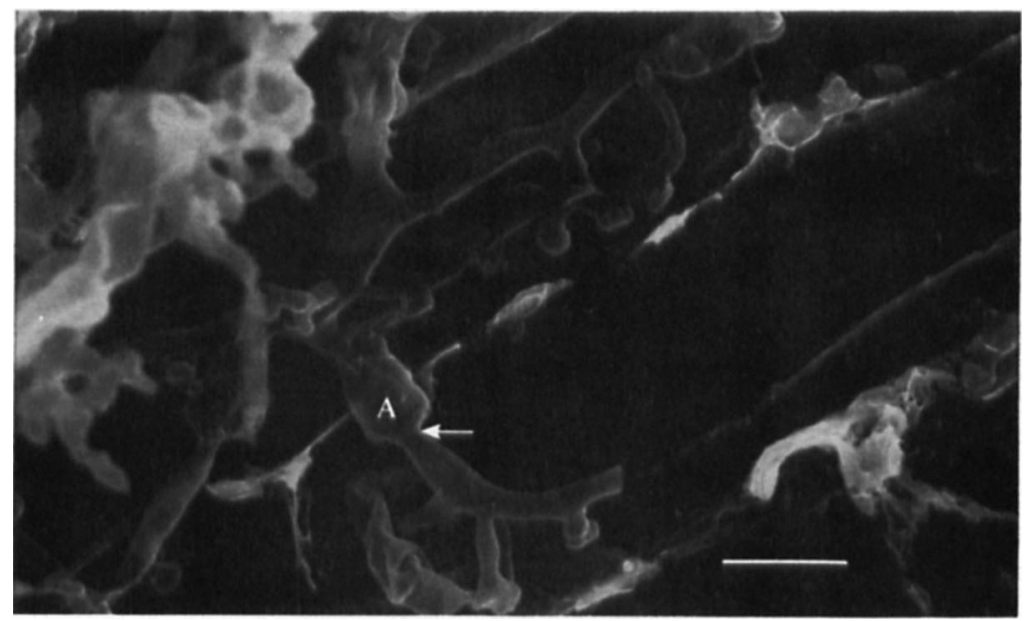

Fig. 6. Longitudinal section of rice straw fragment from the rumen of cattle showing rhizoids with many 'appressoria' on the cell wall and an 'appressorium' (A) which had become an irregular-shaped vesicle after penetrating the cell wall and the penetrating peg denoted by the constricted region (arrow) between the vesicular 'appressorium' and rhizoid. Bar, $5 \mu \mathrm{m}$. 
It should be noted that guinea grass and rice straws which were not incubated in the rumen did not contain any of the fungi similar to those (rumen fungi) described above, thus eliminating the possibility that they were in the feed materials before being ingested by the animals.

Many phycomycete fungi that are plant pathogens produce zoospores which show a preference for encysting and germinating on stomata and their hyphae or rhizoids develop special structures for penetration and absorption of nutrients from the host cells. The present investigation showed that the anaerobic fungi colonizing guinea grass and rice straw in the rumen of cattle and swamp buffalo exhibited a similar behaviour. The parallel behaviour shown by the rumen fungi may indicate that they probably evolved from plant-inhabiting ancestors that became adapted and survived in their anaerobic rumen environment after being ingested by the host animals.

We thank Professor A. Nawawi, Department of Botany, University of Malaya, for his helpful suggestions and comments, Miss Kasmawati Mahmood, Mr Razali Abdullah and Miss Suleka Madhavan, Department of Biology, Universiti Pertanian Malaysia, for their technical assistance and cooperation and the staff of the Electron Microscope Unit, Universiti Pertanian Malaysia, for their assistance with the operation of the SEM.

\section{REFERENCES}

Akin, D. E., Gordon, G. L. R. \& Hogan, J. P. (1983). Rumen bacterial and fungal degradation of Digitaria pentzii grown with or without sulfur. Applied and Environmental Microbiology 46, 738-748.

BAUCHOP, T. (1979a). Rumen anaerobic fungi of cattle and sheep. Applied and Environmental Microbiology $38,148-158$.

BAUCHOP, T. $(1979 b)$. The rumen anaerobic fungi: colonizers of plant fibre. Annales de recherches vétérinaires 10, 246-248.

BAUCHOP, T. (1981). The anaerobic fungi in rumen fibre digestion. Agriculture and Environment 6, 339348.

Johansen, D. A. (1940). Plant Microtechnique. New York: McGraw-Hill.

ORPIN, C. G. (1975). Studies on the rumen flagellate Neocallimastix frontalis. Journal of General Microbiology 91, 249-262.

ORPIN, C. G. (1976). Studies on the rumen flagellate
Sphaeromonas communis. Journal of General Microbiology 94, 270-280.

ORPIN, C. G. (1977a). The rumen flagellate Piromonas communis: its life-history and invasion of plant material in the rumen. Journal of General Microbiology 99, 107-117.

ORPIN, C. G. (1977b). Invasion of plant tissue in the rumen by the flagellate Neocallimastix frontalis. Journal of General Microbiology 98, 423-430.

ORPIN, C. G. $(1981 a)$. Isolation of cellulolytic phycomycete fungi from the caecum of the horse. Journal of General Microbiology 123, 287-296.

ORPIN, C. G. $(1981 b)$. Fungi in ruminant degradation. In Agricultural Science Seminar: Degradation of Plant Cell-wall Material, pp. 37-46. London: Agricultural Research Council.

PEACOCK, P. (1973). Elementary Microtechnique, 4th edn, revised by S. Bradbury. London: Edward Arnold. 